\begin{tabular}{|c|c|c|c|c|}
\hline Compound & $\mathrm{K}$ & $U V_{\text {max }}(n m)$ & $\mathrm{ESI}-\mathrm{MS}^{+} \mathrm{m} / \mathrm{z}$ & Ion detected \\
\hline Catalpol & 1,20 & 200 & 385,11 & {$[\mathrm{M}+\mathrm{Na}]^{+}$} \\
\hline Deacetylasperulosidic acid & 1,41 & 235 & 413,10 & {$[\mathrm{M}+\mathrm{Na}]^{+}$} \\
\hline Aucubin & 1,75 & 200 & 369,12 & {$[\mathrm{M}+\mathrm{Na}]^{+}$} \\
\hline Asperulosidic acid & 2,87 & 235 & 455,11 & {$[\mathrm{M}+\mathrm{Na}]^{+}$} \\
\hline Harpagide & 2,37 & 200 & 387,13 & {$[\mathrm{M}+\mathrm{Na}]^{+}$} \\
\hline Leonuride & 2,43 & 200 & 371,13 & {$[\mathrm{M}+\mathrm{Na}]^{+}$} \\
\hline Galiridoside & 2,57 & 200 & 369,12 & {$[\mathrm{M}+\mathrm{Na}]^{+}$} \\
\hline Loganin & 3,45 & 235 & 413,15 & {$[\mathrm{M}+\mathrm{Na}]^{+}$} \\
\hline Acetylharpagide & 3,50 & 200 & 429,14 & {$[\mathrm{M}+\mathrm{Na}]^{+}$} \\
\hline Ajugoside & 3,67 & 200 & 413,14 & {$[\mathrm{M}+\mathrm{Na}]^{+}$} \\
\hline Oleuropein & 4,29 & 235 & 563,19 & {$[\mathrm{M}+\mathrm{Na}]^{+}$} \\
\hline Harpagoside & 5,17 & 278 & 517,16 & {$[\mathrm{M}+\mathrm{Na}]^{+}$} \\
\hline
\end{tabular}

by UV spectrophotometry and/or electrospray ionization time-of-flight mass spectrometery. Ionization was performed in positive ESI mode. Retention parameters (capacity coefficients K), UV absorbance maxima ( $\left.\lambda_{\max }\right)$, $\mathrm{m} / \mathrm{z}$ values in TOF-MS mode and $\mathrm{m} / \mathrm{z}$ identification are given in Table. The elaborated methodology is destined for the quality assessment of pharmaceutical raw materials and dietary supplements of herbal origin.

\title{
ASSESSMENT OF CORRELATION BETWEEN THE CONTENT OF POLYPHENOLS, PROANTHOCYANIDINS AND ANTIOXIDANT ACTIVITY IN "IN VITRO" TESTS IN FOOD AND MEDICINAL RAW PLANT MATERIALS
}

\section{(C) Perova I. B., Eller K. I.}

Institute of Nutrition RAMS, Moscow, Russia

Proanthocyanidins (OPC) or oligomers of catechins (flavan-3-ols) are among the most widespread forms of polyphenolic compounds of plant origin. According to the U.S. database (USDA Database for the Proanthocyanidin content of selected foods, 2004), proanthocyanidins provide more than $50 \%$ of the daily dietary intake of polyphenols. OPCs are widely used in food dietary supplements, medicinal and prophylactic nutrition and pharmaceuticals, enriched by antioxidants. The aim of this study was to investigate the correlation between the total content of polyphenolic compounds in $\mathrm{g}$ of gallic acid equivalent (GAE),

\begin{tabular}{|l|c|c|c|}
\hline Samples & Polyphenols, \% (g GAE/100g) & OPC, $\%$ & FRSA, trolox equivalent uM/g \\
\hline Cinnamon ground & $37,97 \pm 0,55$ & $5,13 \pm 0,09$ & $77750 \pm 380$ \\
\hline Lingonberry leaves & $13,48 \pm 0,04$ & $3,98 \pm 0,22$ & $2560 \pm 130$ \\
\hline Green tea powdered leaves & $6,65 \pm 0,26$ & $0,49 \pm 0,10$ & $2570 \pm 145$ \\
\hline Birch buds & $5,58 \pm 0,04$ & $0,21 \pm 0,02$ & $2555 \pm 125$ \\
\hline Origanum herb Herba Origani vulgaris & $3,66 \pm 0,04$ & $0,05 \pm 0,01$ & $2580 \pm 140$ \\
\hline Oak bark & $3,53 \pm 0,06$ & $1,05 \pm 0,14$ & $2632 \pm 130$ \\
\hline Green tea leaves & $3,44 \pm 0,06$ & $0,22 \pm 0,05$ & $2543 \pm 145$ \\
\hline Marsh cinquefoil stems Stipes Comari palustris & $2,97 \pm 0,06$ & $2,37 \pm 0,10$ & $2565 \pm 150$ \\
\hline Saint-John's wort herb & $2,58 \pm 0,09$ & $2,02 \pm 0,06$ & $2540 \pm 135$ \\
\hline Cocoa beans & $2,39 \pm 0,02$ & $1,54 \pm 0,09$ & $4375 \pm 170$ \\
\hline Rose hips & $2,21 \pm 0,04$ & $0,34 \pm 0,06$ & $2580 \pm 115$ \\
\hline Willow herb & $1,45 \pm 0,06$ & $0,13 \pm 0,03$ & $2400 \pm 140$ \\
\hline Herba Epilobii & & & $2590 \pm 120$ \\
\hline Walnuts & $1,44 \pm 0,06$ & $0,11 \pm 0,03$ & $2005 \pm 110$ \\
\hline Nutmeg & $1,13 \pm 0,04$ & $1,04 \pm 0,12$ & $3300 \pm 170$ \\
\hline Bilberry (wild) & $0,99 \pm 0,09$ & $0,24 \pm 0,05$ & $10600 \pm 240$ \\
\hline Red kidney beans & $0,95 \pm 0,14$ & $0,45 \pm 0,08$ & $1620 \pm 100$ \\
\hline Walnuts septum & $0,68 \pm 0,07$ & $0,42 \pm 0,06$ & $870 \pm 95$ \\
\hline Red grape peel & $0,47 \pm 0,07$ & $0,8 \pm 0,09$ & $980 \pm 90$ \\
\hline Sour cherry & $0,44 \pm 0,05$ & $0,36 \pm 0,06$ & $1150 \pm 90$ \\
\hline Viburnum opulus berries & $0,43 \pm 0,04$ & $0,19 \pm 0,03$ & $200 \pm 70$ \\
\hline Black currant & $0,16 \pm 0,03$ & $0,28 \pm 0,03$ & \\
\hline
\end{tabular}


concentration of OPCs and antiradical activity in tests "in vitro". More than 40 samples of food and medicinal plants were investigated. Total polyphenolics were determined employing Folin-Ciocalteu photometric method, sum of OPC - by Bate-Smith acid butanol assay, free radical scavengic activity (FRSA) - by the DPPH test.
The study was carried out to search the antioxidant ingredients for diet enrichment. No direct correlation between the antioxidant in vitro tests and the content of polyphenolic compounds and proanthocyanidins has been found. On the basis of the above test results the feasibility of using products based on cinnamon, red beans, cocoa and blueberry for diet enrichment has been shown.

\title{
IN VITRO CYTOTOXIC AND ANTIOXIDANT ACTIVITIES OF SOME PLANT EXTRACTS ON DIFFERENT HUMAN CANCER CELL LINES
}

\author{
(c) El-Hallouty Salwa M. ${ }^{1}$, Khalifa Noha S. ${ }^{2}$, Barakat H. M. ${ }^{2}$, Salim Dina ${ }^{2}$ \\ ${ }^{1}$ Pharmacognosy Department, National Research Centre, Giza, Cairo, Egypt \\ ${ }^{2}$ Botany Department, Ain Shams University, Cairo, Egypt
}

This study involves a bioassay screening of 22 methanol extracts from 19 plants that are commonly used in Egypt for many purposes based on their ethnic values. The aim of this study is to evaluate the cytotoxic and antioxidant activities of 22 methanol extracts. The methanol plant extracts were tested in vitro against four human cancer cell lines (by using MTT method) to determine their cytotoxic effect. The cell viability was examined after $24 \mathrm{~h}$ exposure to $100 \mu \mathrm{g} / \mathrm{ml}$ of the extract in the medium. Negative (dimethyl sulfoxide) and positive ( $A n-$ nonacherimolia methanol extract) controls were simultaneously used. Moreover, the antioxidant effect was determined using DPPH assay. Extracts showing cytotoxic and antioxidant activities were further subjected to determine their (lethal concentration) $\mathrm{LC}_{50}$ and $\mathrm{LC}_{90}$ values. Confirmed in vitro cytotoxic activity was found in four plant extracts. In HepG-2, Cympopogonproximus, Perseaamericana fruits and Vignaunguiculataseeds showed $\mathrm{LC}_{50}=57.4,13.3$ and 56.4 , respectively. In
A-549, Perseaamericana fruits and Tabernamontanadivaricata leaves showed $\mathrm{LC}_{50}=35.4$ and 70.7 , respectively. In HT-29, Cympopogonproximus, Perseaamericana fruits and Tabernamontanadivaricata leaves showed $\mathrm{LC}_{50}=58.6,22$ and 67.5, respectively. In MCF-7, Perseaamericana fruits showed $\mathrm{LC}_{50}=54.5$. In vitro antioxidant activity was confirmed in three plant extracts Ceratoniasiliqua leaves, Perseaamericana leaves, Abrusprecatorius seeds showed $\mathrm{LC}_{50}=10.6,46.5$ and 25.7 , respectively. 5 Extracts out of the 22 studied methanol extracts exhibited potent antioxidant properties when tested at the concentration of $100 \mathrm{ppm}$ against DPPH. The methanol extract of Persea americana leaves, Abrus precatorius seeds, Ceratonia siliqua leaves had $\mathrm{LC} 50=46.5,25.7,10.6 \mu \mathrm{g} / \mathrm{ml}$, respectively Table 4 . The methanol extracts of Ocimum basillicum and Hilianthus annuus had lost their activity below $100 \mathrm{ppm}$. The plants under study may represent promising natural sources for cytotoxic and antioxidant drug discovery.

\section{PHYTOCHEMICAL SCREENING AND ANTIOXIDANT CAPACITIES OF SOME COMPOSITAE PLANTS}

\section{(ㄷ Ergene B. ${ }^{1}$, Bahadır Acıkara Ö. ${ }^{1}$, Bakar F. ${ }^{2}$, Saltan G., Nebioğlu S. ${ }^{2}$}

${ }^{1}$ Ankara University Faculty of Pharmacy, Department of Pharmacognosy, Ankara, Turkey

${ }^{2}$ Ankara University Faculty of Pharmacy, Department of Biochemistry, Ankara, Turkey

Asteraceae is one of the families which include many members containing phenolic compounds (1). The beneficial effects of many of the phenolics in human health have been attributed to their reactive oxygen and nitrogen scavenging and antioxidant capacity. The consumption of vegetables, fruits and flavonoid-rich beverages has been reported to prevent against neurodegenerative diseases, cancer and aging (2). Phenolic compounds have antioxidant potential due to their tendency to act as reducing agents, hydrogen donors, sin- glet oxygen quenchers and metal chelators, chelating agents which can bind metal ions, could be added to enhance the activity of natural preservatives in food stuffs $(2,3,4)$. In this study, the antioxidant activity of three members of Asteraceae family; Crepis foetida subsp. rhoeadifolia, Leontodon crispus var. asper and Pilosella hoppeana subsp. testimonialis were evaluated using 1,1-diphenyl-2-picrylhydrazyl (DPPH) free radical scavenging assay and measuring malondialdehyde measuring levels. In DPPH free radical scavenging activity as- 